\title{
Special aspects of future teachers' training in ensuring information security sphere for university students
}

The article focuses on the future teachers' training experience for ensuring information security in the education system. The relevance of teachers' competent training of information security in the sphere of culture formation of younger generation and ensuring protection of information infrastructure of educational institution is proved. The following phenomena: information overloads; entropy; aggressive mass and communicative influence; resocialization, virtualization; provocation and initiation of conflict situations; primitivization; vulgarization; criminalization and gamization are considered as negative in the digital society by the researchers.The results of the questionnaire among the first- and second-year Bachelor students of Institutes of Energy and Automated Systems and Humanities, Nosov Magnitogorsk State Technical University on questions of destructive influence of the internet information resources are given. The article highlights the methods of students' information security competence formation in the field of internet and information security that were elaborated by the authors. The content of the subject "Information Security" is revealed, the technique and competences formations of future teachers in the sphere of ensuring information security is presented The article supplies with the examples of active methods application for information security training of future bachelors of pedagogical education.

Key words: Information security, information security in education, teachers training, ensuring information security competence, active methods of training, aggressive information environment, destructive informational content

\section{Intoduction}

乌 ntroduction and application of the information and communication technologies (ICT) brings to modern digital society not only positive but negative results either that are connected with violations of information security, with threats of destructive information influences in relation to an individual, social group, the state, and all mankind in general.

"Obviously, the various types of information and communication technologies influence behaviour, the formation of moral standards, the psyche and the lives of future generations. Teachers, psychologists, sociologists specializing in the field of informatization of education, stress the importance of overcoming the negative impact of (mental, moral and physical health), which occurs when using information and communication technologies" [2, p.294].

Of late the world has observed the growth of computer crimes. According to the experts of the Research Center CSIS (Center for Strategic and International Studies), the damage to the global economy from different types of cybercrimes is about $\$ 400$ billion a year. To worsen the situation, different destructive religious, nationalist including extremist movements have become more active and by means of network interaction (social networks, video hostings, forums, blogs, e-mail, etc.) involve young people in their activities.

In the field of information there observed many negative phenomena that require attention of teachers and parents, including: access to inappropriate content (pornography, hate propaganda, drugs, terrorism, offences, crime), hooliganism and criminal actions mediated by the use of information and communication technologies. For example, there is lots extensive easily accessible threatening and indecent information content in the Internet, including advocacy of violence, nationalism, fascism; it is available to get free recipes on drugs and explosives production; besides there proposed pornography (including children's), implanted sectarian preaching, mystical and esoteric teachings and practices, magic, shamanism [2; 14].

According to the current conducted researches the youth is the most vulnerable and weak to destructive influence on the Internet. The researchers discussed the problem from different sides starting from the current state analysis of researches on the problem [4], elaboration of the model of technique formation of information security competence for future teachers of informatics [3], modern requirements and means for information security competence [10], questions of cyber extremism preventive measures in training of future teachers [5], verbal aggression in virtual environment $[13 ; 17]$ and informational ethics teaching for future information technology specialist were also the subject of several researches $[7 ; 12 ; 14-16]$. The descriptions of the educational cyberspace and interaction characteristics with the educational subjects in the context of modal logic are also offered [1].

The number of young people who have request undesirable internet content, increases in the world. About $80 \%$ of participants of extremist organizations are persons whose age does not exceed 30 years including minors of 14-18 years.The survey "Adults and Children in the Digital World", that was conducted in April 2018, by Kaspersky Lab, one of the world's largest Rus- 
sian companies that works in the field of information security, showed that $20 \%$ of students received invitations to make friends from unfamiliar adults; $49 \%$ of schoolchildren surfed websites for adult; $30 \%$ of schoolchildren have faced bulling or came across cyberbullying cases; $21 \%$ of schoolchildren have friends who watch cruel videos, $10 \%$ of schoolchildren have got experience of meeting people with whom they got acquainted in the network. (fig. 1)
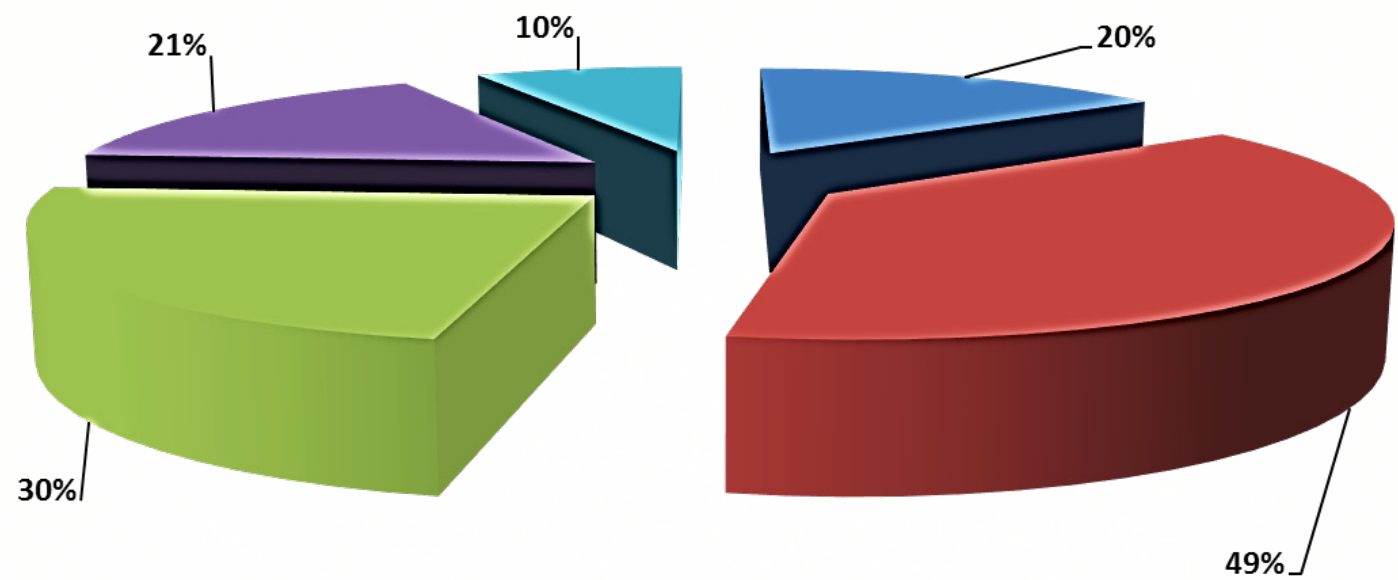

- received invitations to make friends from unfamiliar adults

n surfed websites for adults

$\square$ faced, or came across cyberbullying cases

nave friends who watch cruel video

- have got experience of meeting with people with whom they got acquainted in the network

Fig. 1 Statistics of the Research "Adults and Children in the Digital World"

In the digital society researchers consider the following negative phenomena: information overloads; entropy; aggressive mass and communicative influence (promotion of hatred and violence, misinformation, manipulation with consciousness, distribution of rumours, etc.); resocialization (substitutions of real life in human society with virtual life on the Internet); virtualization (ignoring or virtualization of responsibility); provocation and initiation of conflict situations; primitivization (simplification of forms, ways of communication); vulgarization (promoting of slang and abuse expressions, pornographies in internet content); criminalization; an gamization (process of penetration of various elements of the game world to other spheres of life) and so forth.

Linguistic aggression of the virtual space is being somewhat aggravated by the environment of its existence. Like any other phenomenon borrowed by the virtual space from the real one, the language takes on some additional characteristics and features. For example, unlike the real space, the virtual space has only the written implementation, and therefore eliminates the additional connotative shades, which can be expressed by facial expressions, emotions, behaviour, speaking etc., but has compensation in the form of emoticons and pictograms. Moreover, the communication within the virtual space abounds with pragmatically-dyed particles expressing some arrogance or austerity in relation to the addressee, reproach, disappointment, doubt upon the veracity of the addressee, irritation and threat, besides, the communication in virtual space has no real possibility of visual evaluation of communicants, behind the avatars there are often "hidden" not those who are in them. A hypothetical opportunity to be recognized provokes dialogue which in the real visual communication a person cannot afford because of social and moral norms and subsequent punishment [6].

Destructive influence of internet information resources is revealed in violations of physical and mental health of users, in causing damage in personal, social, economic, political spheres. The youth is a target for negative information and psychological impacts of the Internet. The youth is most inclined to addictive, asocial and delinquent behaviour in the ICT environment and it is also very vulnerable for ideas of "colour" and "Twitter" revolutions, violent extremism, xenophobia, intolerance and terrorist radicalization.Internet addiction causes also various economic problems: owners' huge losses from piracy production, damage from surfing social networks during working hours and internet users waste money on unreasonable online purchases and so forth. 
The methodological basis of the work is presented with the following methods: theoretical analysis, material study of scientific and periodicals on the problem, documentary analysis, expert survey, questioning, observation.
Users can be exposed to various internet threats in the network. Table 1 represents the results of the survey that was conducted among the fist- and second-year bachelor students of Institute of Energy and Automatic Systems, and Institute of Humanities, Nosov Magnitogorsk State Technical University [16].

Questioning Results of the 1 and 2-courses Bachelors (May, 2017)

Table 1

\begin{tabular}{|c|c|c|c|c|c|}
\hline \multirow{3}{*}{ Questions } & \multirow{3}{*}{ Variants of the answers } & \multicolumn{4}{|c|}{ Results of questioning } \\
\hline & & \multicolumn{2}{|c|}{$1(33)$} & \multicolumn{2}{|c|}{$2(34)$} \\
\hline & & $\begin{array}{c}\% \text { Bachelors } \\
\text { who } \\
\text { answered }\end{array}$ & $\begin{array}{l}\text { The number } \\
\text { of participants }\end{array}$ & $\begin{array}{c}\text { \% Bachelors } \\
\text { who } \\
\text { answered }\end{array}$ & $\begin{array}{l}\text { The } \\
\text { number of } \\
\text { participants }\end{array}$ \\
\hline 1 & 2 & 3 & 4 & 5 & 6 \\
\hline \multirow{4}{*}{$\begin{array}{l}\text { Have you ever suffered } \\
\text { from negative impacts } \\
\text { on the Internet? }\end{array}$} & $\begin{array}{l}\text { a) suffered from being } \\
\text { abused }\end{array}$ & 42,42 & 14 & 38,25 & 13 \\
\hline & $\begin{array}{l}\text { b) suffered from } \\
\text { cyberbulling }\end{array}$ & 39,39 & 13 & 44,11 & 15 \\
\hline & c) suffered from trolling & 18,19 & 6 & 17,64 & 6 \\
\hline & $\begin{array}{l}\text { d) never suffered from } \\
\text { negative impacts on the } \\
\text { Internet }\end{array}$ & 0 & 0 & 0 & 0 \\
\hline \multirow{4}{*}{$\begin{array}{l}\text { In which of the net } \\
\text { environments did you } \\
\text { come across these } \\
\text { actions? }\end{array}$} & a) social networks & 63,63 & 21 & 64,8 & 22 \\
\hline & b) comments on a website & 6,07 & 2 & 2,94 & 1 \\
\hline & c) online games & 24,24 & 8 & 29,41 & 10 \\
\hline & d) forums & 6,06 & 2 & 2,94 & 1 \\
\hline \multirow{8}{*}{$\begin{array}{l}\text { Choose three the most } \\
\text { widespread threads on } \\
\text { the Internet }\end{array}$} & a) verbal aggression & 12,12 & 4 & 14,7 & 7 \\
\hline & $\begin{array}{l}\text { b) informational } \\
\text { manipulation }\end{array}$ & 9,09 & 3 & 11,76 & 4 \\
\hline & c) spam & 15,15 & 5 & 11,76 & 4 \\
\hline & d) cyber fraud & 12,12 & 4 & 14,7 & 5 \\
\hline & e) malicious programmes & 15,15 & 5 & 17,6 & 6 \\
\hline & f) cyberbulling & 12,12 & 4 & 2,94 & 1 \\
\hline & g) undesired content & 18,19 & 6 & 5,88 & 2 \\
\hline & h) cyberterrorism & 6,06 & 2 & 14,7 & 5 \\
\hline
\end{tabular}

Teachers play the main role in pedagogical diagnostics, prophylactic measures and corrections of negative information impacts on children and youth on the Internet. Priorities of the digital society include not only improvement of training systems in the sphere of information security, but also formation of information security competence among university undergraduates of pedagogical directions."In the modern world information takes an important part not only in the real world but also in the virtual one. The informational digital environment has great impact on present life and this influence is mainly viewed in its forms of information, teaching, entertaining, connecting or even uniting." [17]
Dealing with the development of separate aspects of the problem, we came to a conclusion that in the system of the higher education there is a problem that is connected with generalization, systematization of researches, development of a complex of theoretic and methodological bases and methodical supplementation of creating the concept and pedagogical model of information security competence formation among university students.

At the same time information security competence of a future teacher is understood as the integrated characteristic of a personality's qualities that allows carrying out his professional and social activity taking into account information secu- 
rity requirements to their safety activity $[5,9,11$ and etc.]. It is determined by the set of motives and values of the personality to self-development in the field of information security, by knowledge of information security bases, skills and successful experience of protection information infrastructure of educational institution (professionally significant information) and also by emotional stability and ability to resist to threats of information safety.
Discussion

While conducting the research on the ways of improving the system of future teachers of informatics training to the ensuring information security in teaching and educational process of higher education institution we elaborated a technique of information security competence formation among students. The generalized model of a technique of information security competence formation is presented in Table 2 [11].

\section{Technique formation model of competence in ensuring information security}

Table 2

\section{STANDARD AND TARGET BLOCK}

Social order of society and state: training of informatics teachers who will acquire digital security competence

Requirements of Federal State Educational Standard

of Higher Professional Education for direction 44.03.05

"Pedagogical Education" to the level of training in the field of information security and protection of information

Goals: formation of skills at future teachers of informatics in the field of the ensuring information security in the course of vocational training.

\begin{tabular}{|c|c|}
\hline \multicolumn{2}{|c|}{ METHODOLOGICAL BLOCK } \\
\hline $\begin{array}{l}\text { Approaches: } \\
-\quad \text { valuable-oriented; } \\
-\quad \text { competence -oriented; } \\
-\quad \text { individual and active. }\end{array}$ & $\begin{array}{l}\text { Principles: } \\
\text { - } \quad \text { formation of valuable orientations of developing and } \\
\text { bringing up training and personal focused education; } \\
\text { - } \quad \text { developing and bringing up training; } \\
\text { - } \quad \text { personal focused education; } \\
\text { independent work, formation of problem solution } \\
\text { experience, self-expressing and development of } \\
\text { identity of students; } \\
\text { - } \quad \text { self-realization and development of students' } \\
\text { identity; } \\
\text { - } \quad \text { activity; } \\
\text { - } \quad \text { integrity; } \\
\text { - } \quad \text { consciousness and activity of students. }\end{array}$ \\
\hline
\end{tabular}

\section{CONTENT-ORGANIZING BLOCK}

Content of the generalized special competence "he is capable to ensure the information security and protection of information in key spheres of his future professional activity":

- $\quad$ he is capable to develop and carry out educational modules of programs of basic and elective courses on information security problems at various educational steps in various educational institutions;

- $\quad$ he is capable to form and use secure digital information and education environment;

- he is capable to conduct scientific research on a humanitarian component of a information security problem and to apply results of scientific researches for solving specific educational tasks;

- he is ready to investigate, make projects, organize and estimate realization of administrative process with use digital informational educational environment (DEEI) (EIOS);

- he is ready to implementation of pedagogical project in digital informational educational environment, of educational programs and individual educational routes on problems of information security and protecting information;

- he is ready to development and realization of information security training techniques and supplying security of digital informational educational environment;

- he is capable to study and form the cultural needs, to raise cultural and educational level of population concerning information security.

\section{Competence components}

Motivational component

\section{Cognitive component}

Behavioural component
Valuable and semantic component
Emotional and strong-willed component

The life cycle of competence (stages)

Stage of formation

Stage of perfection

Stage of application 


\section{Organizational and pedagogical conditions of competence formation:}

- ensuring orientation of content of training and educational process on counteraction to the destructive phenomena in a cyberspace at all stages of vocational training of informatics teachers;

- formation of subjective positions of future teachers of informatics in the field of providing information security by their inclusion into regular project and reflexive activity at classes in higher education institution;

- $\quad$ students' training for formation of their experience in protecting information infrastructure of educational institution against threats of information influences by means of elaboration of a special course "Information security in the system of open education".

\section{Methodological support of formation of competence}

\begin{tabular}{|c|c|c|}
\hline $\begin{array}{l}\text { Forms: } \\
\text { - } \quad \text { lecture, } \\
\text { - } \quad \text { laboratory work, } \\
\text { - } \quad \text { business games, } \\
\text { - } \quad \text { an educational conference, } \\
\text { - } \quad \text { educational and professional } \\
\quad \text { practices, } \\
\text { - } \quad \text { research work }\end{array}$ & $\begin{array}{l}\text { Methods: } \\
\text { - } \text { method of projects, } \\
\text { - } \text { game, } \\
\text { - } \text { research, } \\
\text { - } \text { case-study and experience of } \\
\text { practical activities, } \\
\text { brain-storming }\end{array}$ & $\begin{array}{l}\text { Means: } \\
\text { - } \quad \text { printing, } \\
\text { - } \quad \text { audio, } \\
\text { - } \quad \text { misual, } \\
\text { - Internetimedia resources, } \\
\text { - } \quad \text { hardware and software systems, } \\
\quad \text { etc. }\end{array}$ \\
\hline
\end{tabular}

\section{ESTIMATION AND PRODUCTIVE BLOCK}

Criteria of competence formation: motivational, cognitive, behavioural, valuable and semantic, emotional and strong-willed

\begin{tabular}{|c|c|c|c|c|}
\hline Motivational criteria & Cognitive criteria & Behavioural criteria & $\begin{array}{c}\text { Valuable and } \\
\text { semantic criteria }\end{array}$ & $\begin{array}{c}\text { Emotional and strong } \\
\text { criteria }\end{array}$ \\
\hline
\end{tabular}

\begin{tabular}{|l|l|}
\hline \multicolumn{1}{|c|}{ Levels of competence formation } \\
\hline \multicolumn{1}{|c|}{ Threshold level } & Basic level \\
\hline Result: & Advanced level \\
\hline $\begin{array}{l}\text { Passing of a future teacher of informatics to higher level of formation of competence in ensuring information } \\
\text { security }\end{array}$ \\
\hline
\end{tabular}

The problems of ensuring information security are considered in various subjects of the curriculum of bachelors' in pedagogical education direction training (Law, Basics of Life Safety, etc.). However, the level of information security competence formation with these subjects is obviously insufficient in the conditions of the developing information society.

"Computer-mediated communication is a new social reality that is self-regulating and functioning according to its own rules and laws. In terms of scale, computer-mediated communication is mass - communication with the whole world, intrapersonal - communication between the user and a computer, and group communication - communication between groups of people" [8, p.37].

We find possible realization of the elaborated technique within teaching the subject "Information Security" which should be included in all future teachers' training curricula. The aim of studying the subject "Information Security" is training of future teacher students with the principles and means of ensuring of information security of school students personality, concrete educational objects and institutions, societies and the states in general.

Table 3

Content of the subject "Information security" for bachelor students of Pedagogical Education Direction

\begin{tabular}{|l|l|}
\hline \multicolumn{1}{|c|}{$\begin{array}{c}\text { Main Sections of } \\
\text { subjects }\end{array}$} & \multicolumn{1}{c|}{ Contents of the Section } \\
\hline $\begin{array}{l}\text { 1. Bases of } \\
\text { information security } \\
\text { and protecting of } \\
\text { information }\end{array}$ & $\begin{array}{l}\text { 1.1. Relevance of the problem safety ensuring in the digital society. } \\
\text { 1.2. Basic concepts and definitions of information safety. } \\
\text { 1.3. Main components of information security. }\end{array}$ \\
\hline $\begin{array}{l}\text { 2. Legislative, } \\
\text { standard and legal } \\
\text { levels of ensuring } \\
\text { information security }\end{array}$ & $\begin{array}{l}\text { 2.1. Types of measures of ensuring information security. } \\
\text { 2.2. Standards and specifications in the field of information security. } \\
\text { 2.3. Mrganizational ethical standards of behavior in the digital world. } \\
\text { institutions. }\end{array}$ \\
\hline
\end{tabular}




\begin{tabular}{|c|c|}
\hline $\begin{array}{l}\text { 3. Administrative and } \\
\text { procedural levels of } \\
\text { ensuring information } \\
\text { security }\end{array}$ & $\begin{array}{l}\text { 3.1. Risk analysis of information security. } \\
\text { 3.2. Policy of information security. } \\
\text { 3.3. The program of works in the field of ensuring information security. } \\
\text { 3.4. Main classes of measures of procedural level: human resource management; physical } \\
\text { protection; maintenance of working capacity; response to violations of the mode of safety; } \\
\text { planning of recovery work. }\end{array}$ \\
\hline $\begin{array}{l}\text { 4. The main of } \\
\text { programme technical } \\
\text { measures of ensuring } \\
\text { information security }\end{array}$ & $\begin{array}{l}\text { 4.1. Basic concepts of programme technological level of information security. } \\
\text { 4.2. The features of modern information systems essential from the point of view of safety. } \\
\text { 4.3. Identification and authentication, access management. } \\
\text { 4.4. Coding, integrity control. } \\
\text { 4.5. Analysis of security. Ensuring high availability. }\end{array}$ \\
\hline $\begin{array}{l}\text { 5. Information } \\
\text { security in education }\end{array}$ & $\begin{array}{l}\text { 5.1. Main risks and threats of information security of educational institution. } \\
\text { 5.2. Safe use of the Internet in educational institution. } \\
\text { 5.3. Anti-virus protection of information resources of educational institution. } \\
\text { 5.4. Content filtration. } \\
\text { 5.5. Personal Data Protection. } \\
\text { 5.6. Safety of pupils when using information technologies: } \\
\text { - prevention and counteraction of cyberextremism ideology among the youth; } \\
\text { - destructive groups in the Internet; } \\
\text { - correction of deviant (addictive, delinquent) behaviour of school students in ICT sphere. }\end{array}$ \\
\hline
\end{tabular}

In order to solve the problems of activating the educational and cognitive activity of students of Institutes of Energy and Automated Systems and Humanities, Nosov Magnitogorsk State Technical University in the process of learning information security and protecting information, we used a variety of active teaching methods, such as mental maps, case-study method, project method, etc. (see Table 2, "Methodological support for the formation of competence") $[15 ; 16]$

Application of active teaching methods in the formation of competencies in future teachers in the field of information security showed significant raise of motivation that is aimed at studying and applying information protection methods; lectures highlights the positive influence of methods on students' ability to generate, structure and classify ideas, collect and analyze information, propose alternative solutions, effectively interact with each other and solve emerging problems.

\section{Conclusion}

The further studying and implementation of our scientific and methodological results in the educational process is expected:

- Discussion of problems in the sphere of individual stability formation to negative forms of internet influence at classes with Bachelors and Masters and at methodological seminars with Post-graduate stu- dents and young teachers;

- Modernization and elaboration of new curricula for disciplines of higher and postgraduate vocational education, refreshment courses for raising scientific and professional qualifications with taking into account the scientific and methodological developments of the study;

- Introduction of new topics on information security into the curricula as a regional component and selective disciplines for specialized directions of training and higher education directions of training, the system of postgraduate education for scientific and pedagogical staff;

- actualization of themes and the subject of research work for students, young scientists, teachers and graduate students;

- application of project materials for course and degree and qualification papers, etc.

Materials of the work are supposed to be used:

- For conducting research and scientific work with students, university lecturers, for conferences, round tables, meetings of scientific schools and research laboratories;

- for writing textbooks, manuals for students of ICT areas (Pedagogical education (direction "Informatics and Economics", "Primary Education and Informatics"), "Applied Informatics", "Business Informatics", etc.). 
1. Abdurazakov M.M., Korotenkov Yu.G., Muhidinov. M.G.. Educational space representation in cyberspace // SHS Web of Conferences. 2016. V. 29. Available at: http://www.shs-conferences.org/articles/shsconf/abs/2016/07/ contents/contents.html. (accessed 3 August 2018). DOI: http://dx.doi.org/10.1051/shsconf/20162901001

2. Chernova E.V. Teachers Training for Prevention of Pupils Deviant Behavior in ICT // Conference on Information Technologies in Science, Management, Social Sphere and Medicine (ITSMSSM-2016). Conference proceedings. Atlantis Press, 2016.

3. Chusavitin M.O. Model of Technique Formation of Information Security competence for Future Teachers of Informatics // New Information Technologies In Education: Materials of the VII International Scientific and Practical Conference. Ekaterinburg, RGPPU Publ., 2014.

4. Davletkireeva L.Z., Novikova T.B. Current state analysis of researches on the problem of university students' resistance formation to technologies of negative information and psychological impact on the internet. Modern high technologies. 2016. no. 11-2.

5. Chusavitina G.N., Kurzayeva L.V., Davletkireeva L.Z., Chusavitin M.O. Future teachers training for ensuring information security. Magnitogorsk, NMSTU Publ., 2017.

6. Chusavitina G., Zerkina N. Cyber extremism preventive measures in training of future teachers // International multidisciplinary scientific conference on social sciences and arts SGEM. 2015. Vol. 2.

7. Chusavitina G., Zerkina N. Informational ethics teaching for future information technology specialist // International multidisciplinary scientific conference on social sciences and arts SGEM. 2015. Vol. 2.

8. Karmanova E.V. Use of network services a web 2.0 for realization of design approach in information security training. Informatics and education. 2018. no. 4 (293). pp. 27-36.

9. Chusavitina G.N., Musiychuk M.V. Pedagogical aspects of the problem of counteraction to threats on the Internet. Mir Nauki, 2017, Vol. 5, no. 6.

10. Kurzaeva L.V. Future teachers' competence forming in the sphere of information security: modern requirements \& means // Conference on Information Technologies in Science, Management, Social Sphere and Medicine (ITSMSSM-2016). Conference proceedings. Atlantis Press, 2016.

11. Kurzayeva L.V. On the Question of Requirements Formation to the Personal Information Security Competences in the System of Higher Education. Fundamental Researches. 2013. no. 8. p. 5.

12. Nedosekina A.G. Esthetic Ideal Formation as a Means of Cyberextremism prevention. Fundamental Researches. 2014. no. 12. p. 5.

13. Zerkina N.N., Lomakina E.A., Chusavitina G.N. Verbal aggression in virtual environment. Modern Journal of Language Teaching Methods. 2017. Vol. 7.

14. Zerkina N.N. Linguistic and Ethic Transformations in Communication of Internet Environment. Polidiscourse Environment: Word, Text, Communication. NMSTU, 2017. pp. 36-50.

15. Zerkina N.N., Chusavitina G.N. Cyber Extremism Preventing Actions In Modern System Of Higher School As A Social Challenge. Internet-Journal "Obshestvo, Gosudarstvo, Pravo» ("Society, State, Law"). 2016. Vol. 1. Available at: http://gosuprav.ru/issue-1-19-2016.html (accessed 1 October 2018)

16. Zerkina N.N., Chusavitina G.N. Elaboration of approaches to internet negative impact resistance for university students // 8th World Conference on Educational Sciences (WCES-2016). Abstracts book. Academic World Education and Research Center, Non-profit international organization. 2016. pp. 231-237

17. Zerkina N.N., Lomakina E.A. Linguistic And Digital Characteristics Of Modern Infomation Environment. Russian Linguistic Bulletin. 2017. no. 2 (10). pp. 16-18. DOI: https://dx.doi.org/10.18454/RULB.10.11

Информация об авторах

Чусавитина Галина Николаевна (Россия, г. Магнитогорск)

Профессор, кандидат педагогических наук зав. кафедрой бизнес информатики и информационных технологий

Магнитогорский государственный технический университет им. Г.И. Носова E-mail: gala_m27@mail.ru

\section{Зеркина Наталья Николаевна} (Россия, г. Магнитогорск)

Доцент, кандидат филологических наук зав. кафедрой иностранных языков по техническим направлениям

Магнитогорский государственный технический университет им. Г.И. Носова E-mail: agatik01@mail.ru

\section{Information about the authors}

Galina N. Chusavitina

(Russia, Magnitogorsk) Professor,

$\mathrm{PhD}$ in Pedagogical Sciences

Head of the Department of Business Informatics and Information Technologies

Nosov Magnitogorsk State Technical University E-mail: gala_m27@mail.ru

Natalia N. Zerkina

(Russia, Magnitogorsk)

Associate Professor,

$\mathrm{PhD}$ in Philological Sciences

Head of the Department of Foreign Languages by Technical Directions

Nosov Magnitogorsk State Technical University E-mail: agatik01@mail.ru 
Макашова Вера Николаевна

(Россия, г. Магнитогорск)

Доцент, кандидат педагогических наук, доцент кафедры бизнес информатики и информационных технологий

Магнитогорский государственный технический университет им. Г.И. Носова makashova.vera@mail.ru
Vera N. Makashova

(Russia, Magnitogorsk)

Associate Professor,

$\mathrm{PhD}$ in Pedagogical Sciences

Associate Professor at the Department of Business

Informatics and Information Technologies

Nosov Magnitogorsk State Technical University

E-mail:makashova.vera@mail.ru

\section{For Reference ${ }^{\text {APA }}$}

Chusavitina, G. N., Zerkina, N. N., \& Makashova V. N. (2018). Special aspects of future teachers' training in ensuring information security sphere for university students. Perspektivy nauki i obrazovania-Perspectives of Science and Education, 35 (5), 259-266. doi: 10.32744/pse.2018.5.29. (In Russ., abstr. in Engl.) 